\title{
Radical Transurethral Resection for Prostate Cancer Might Affect the Disputes about Prostate-Specific Antigen Screening: Suggestions Obtained from Radical Transurethral Surgery
}

\author{
Masaru Morita $^{1} \&$ Takeshi Matsuura ${ }^{2}$ \\ ${ }^{1}$ Kounaizaka Clinic, Kochi, Japan \\ 2 Department of Urology, Matsubara Tokushukai Hospital, Osaka, Japan \\ Correspondence: Masaru Morita, Kounaizaka Clinic, 1917-3 Asakura-Hei, Kochi, Kochi 780-8063, Japan. \\ Tel/Fax: 81-88-843-8833. E-mail: qq6e49qg9@chime.ocn.ne.jp
}

Received: August 29, $2013 \quad$ Accepted: September 25, $2013 \quad$ Online Published: September 30, 2013
doi:10.5539/cco.v2n2p62
URL: http://dx.doi.org/10.5539/cco.v2n2p62

\begin{abstract}
To find an answer to the argument whether prostate specific antigen (PSA)-based mass screening would be beneficial or inexpedient for patients, we analyzed our result of 150 radical transurethral resection of prostate cancer in 126 patients with stage T1c disease. Preoperative PSA ranged from 2.00 to $66.3 \mathrm{ng} / \mathrm{mL}$ (median, 5.65). The median follow-up periods of the 115 patients except for 11 dropouts were 63.8 months. PSA recurrence developed in nine patients $(7.8 \%)$. The other 106 patients have stable PSA as follows: PSA $\leq 0.01,42$ patients; $\leq$ 0.02, 19 patients; $\leq 0.03,10$ patients; $\leq 0.04,6$ patients; $\leq 0.1,10$ patients, $\leq 0.2,7$ patients; $\leq 0.9,12$ patients. PSA nonrecurrence rates according to D'Amico's risk group were $100 \%$ for the low-risk group, $93 \%$ for the intermediate-risk group and $79 \%$ for the high-risk group. The most frequent complication was bladder neck contracture (developed in $33.0 \%$ of patients) and easily treated by optical urethrotomy. Postoperative urinary incontinence was temporary and disappeared within 3 months. Erectile function was preserved in $51.3 \%$. We obtained satisfactory oncological and functional outcomes in patients with T1c prostate cancer by RTUR-PCa. Proper indication of the procedure with much longer follow-up might affect the dispute that PSA mass screening might tend to be overdiagnosis and overtreatment as long as PSA screening was properly indicated.
\end{abstract}

Keywords: PSA screening, T1c prostate cancer, radical transurethral resection, focal transurethral resection, TURP

\section{Introduction}

The draft recommendation by The United States Preventive Services Task Force (USPSTF) opposing prostate-specific antigen (PSA) screening for prostate cancer (PCa) issued on October 7, 2011, has brought not a little confusion to most urologists because prostate cancer morbidity and mortality rates are getting increased gradually. Current recommendation was finalized and released in May 2012 (LeFevre, 2012). Reported mortality by Prostate, Lung, Colon, and Ovarian Cancer Screening Trial (PLCO trial) (Andriole et al., 2009) also did not result in supporting the role of PSA screening. On the contrary, the report by European Randomized Study of Screening for Prostate Cancer (ERSPC) (Roobol et al., 2009) and a report from Sweden showed that prostate cancer mortality was reduced (Hugosson et al., 2010). The most recent guideline of American urological Association does not recommend routine screening but states men ages 55 to 69 years with average risk appears to have the greatest benefit of screening (Carter et al., 2013). Urologists are now urged to make a difficult decision how to evaluate PSA screening for prostate cancer.

As to the current postoperative complications of open radical prostatectomy for localized prostate cancer, urinary incontinence is reported to develop in about $20 \%$ of patients and loss of erectile function in about $30 \%$. Irradiation therapy also has a 17\% risk of erectile dysfunction and intestinal damages as well (Chou et al., 2011). Watchful waiting or active surveillance have not yet established as a satisfactory treatment (Bill-Axelson et al., 2008; Wilt et al., 2009). There might be a definite drawback that nothing active is to be done despite the confirmed diagnosis of cancer, and patients with cancer might be hard to accept the policy due to a possible harmful psychological influence. Concerning robot-assisted laparoscopic prostatectomy (Binder \& Kramer, 2001; Menon et al., 2007), it is suggested that patients should not expect fewer rates of complications (Hu et al., 2009; 
Barry, Gallagher, Skinner, \& Fowler, 2012). Urologists now have to pursue less invasive treatment methods such as focal therapy or make current standard therapy less invasive. Less invasive procedures might justify PSA screening and end the dispute of overdiagnosis and overtreatment. We reported radical transurethral resection of prostate cancer (RTUR-PCa) for localized prostate cancer (Morita \& Matsuura, 2009; 2011; 2013), and we applied it to focal transurethral resection of prostate cancer (FTUR-PCa) as a focal therapy to seek better functional outcomes (Morita \& Matsuura, 2012). The idea of a transurethral approach to resect almost total prostate tissues containing PCa dates back to around 1990 (Valdivia Uría \& López López, 1989; Reuter, Reuter, $\&$ Epple, 1991), and the technique did not significantly increase the operative morbidity and mortality compared with transurethral resection of the prostate (TURP) for benign prostate hyperplasia (BPH). A recent report with a large number of patients and a longer follow-up period suggests that the procedure might be a valid alternative in some selected patients with PCa (Reuter \& Dietz, 2009). To decide the efficacy of such less invasive treatment in the similar patient category as diagnosed by PSA screening, we here report our result of RTUR-PCa for T1c prostate cancer classified by tumor-nodes-metastasis (TNM) classification of 1997.

\section{Materials and Methods}

\subsection{Patients}

We performed 150 radical TUR-PCa's in 126 patients with stage T1c localized prostate cancer between June 2004 and January 2010. A total of 115 patients were included in the present study excluding 11 patients who were lost to follow-up. Patients' age ranged from 52 to 92 years (mean $\pm \mathrm{SD}, 71.6 \pm 7.8$; median, 72.0 ) and preoperative PSA, 2.00 to $66.30 \mathrm{ng} / \mathrm{mL}$ (mean $\pm \mathrm{SD}, 7.80 \pm 7.47$; median, 5.65). We informed the patients that the procedure was not a standard radical surgery, and those who did not agree with the procedure were excluded from the study. We also excluded patients who might have risks of severe complications by standard TURP. Patients who provided written informed consent were eligible to participate in the study, which was approved by the institutional review board after a preliminary study. We performed ultrasound-guided transrectal biopsy preoperatively taking 14 samples.

Before surgery, 79 patients were taking hormonal therapy using oral chlormadinone acetate for the period between 1 and 47 months. In some patients hormonal therapy had been started in the previous hospital, and the other patients had selected to take hormonal therapy at the time of diagnosis. A total of 36 patients after December 2007 did not take preoperative hormonal therapy.

\subsection{Transurethral Surgery}

One authorized urologist (M. M.) performed all the surgeries. We used a standard TURP setup with an irrigation pressure of $80 \mathrm{cmH}_{2} \mathrm{O}$ and an irrigation rate of $250 \mathrm{~mL} / \mathrm{min}$ using D-sorbitol solution. First, we resected the central and transition zone, and then tried to resect and fulgurate peripheral zone completely. We continued the resection until adipose tissue, venous sinus, or the external sphincter was identified. Instead of resecting more deeply, we aggressively fulgurated the prostate bed next to the area where adipose tissue or venous sinus was exposed because the remaining prostate tissue could be a thin layer there. We especially paid attention not to distend the bladder too much preventing a high irrigation pressure and a resultant transurethral resection (TUR) syndrome. Special attention was also paid to avoid injuries to Santorini's plexus and the rectum. The procedure was started from the 12 o'clock position, dividing the prostate into 6 parts, and resected specimens were collected separately to examine the distribution of cancer. The seminal vesicle was partially resected at its attached part to the prostate between the 4 and 8 o'clock positions to determine the invasion of cancer. The verumontanum was finally resected to achieve complete resection. The bag catheter was removed at the third postoperative day.

\subsection{Follow-up}

Postoperative PSA was measured every 2 months starting 2 months after the surgery. PSA failure was suspected when PSA showed a consecutive rise more than $0.2 \mathrm{ng} / \mathrm{mL}$. If the PSA level reached a plateau between 0.2 and $1.0 \mathrm{ng} / \mathrm{mL}$, we did not immediately think treatment failure had occurred. These criteria were also applied to the indication of the second RTUR-PCa. We evaluated stress urinary incontinence by asking patients about the postoperative status of urinary leak on cough or sneeze and needs for urinary pads.

\section{Results}

\subsection{The First and the Second Surgery}

The operation time and the mean resected weight ranged 70 to 150 minutes (mean, 90; median, 90) and 5 to 63 grams (mean, 17.5; median, 16.0) for the first operation, and 40 to 70 minutes (mean, 61; median, 65) and 5 to 12 grams (mean, 6.9; median, 7.0) for the second operation. 
All the patients were clinically diagnosed having T1c prostate cancer. The pathological stages were the following: pT0, 1 case; pT2a, 51 cases; pT2b, 62 cases; pT3, 1 case (Table 1). Gleason scores (GS) were the following: GS 4, 3 patients; 5, 3 patients; 6, 32 patients; 7, 56 patients, 8, 14 patients; 9, 7 patients (Table 2). Out of 11 patients who were lost to follow-up, 6 patients went to the other hospital, 4 didn't return to the clinic and 1 refused the second transurethral surgery.

Table 1. Results of RTUR-PCa grouped by pathological stage

\begin{tabular}{|c|c|c|c|c|c|c|c|c|c|c|}
\hline \multirow{3}{*}{$\begin{array}{l}\text { Pathological } \\
\text { Stage }\end{array}$} & \multirow{3}{*}{$\begin{array}{l}\text { No. } \\
\text { Patient }\end{array}$} & otal Patients & \multicolumn{4}{|c|}{ Patients treated with 1 operation } & \multicolumn{4}{|c|}{ Patients treated with 2 operations } \\
\hline & & \multirow{2}{*}{$\begin{array}{l}\text { Preop PSA } \\
\text { Mean(SD) } \\
\text { Median(Range) }\end{array}$} & \multirow{2}{*}{$\begin{array}{l}\text { No. } \\
\text { Patient }\end{array}$} & \multicolumn{2}{|c|}{$\begin{array}{c}\text { Patients with stable PSA } \\
\text { after TUR }\end{array}$} & \multirow{2}{*}{$\begin{array}{l}\text { No. } \\
\text { PSA } \\
\text { Failure }\end{array}$} & \multirow{2}{*}{$\begin{array}{l}\text { No. } \\
\text { Patient }\end{array}$} & \multicolumn{2}{|c|}{$\begin{array}{c}\text { Patients with stable PSA } \\
\text { after TUR }\end{array}$} & \multirow{2}{*}{$\begin{array}{l}\text { No. } \\
\text { PSA } \\
\text { Failure }\end{array}$} \\
\hline & & & & $\begin{array}{l}\text { No. } \\
\text { Patient }\end{array}$ & $\begin{array}{l}\text { Latest PSA } \\
\text { Mean(SD) } \\
\text { Median(Range) }\end{array}$ & & & $\begin{array}{l}\text { No. } \\
\text { Patient }\end{array}$ & $\begin{array}{l}\text { Latest PSA } \\
\text { Mean(SD) } \\
\text { Median(Range) }\end{array}$ & \\
\hline pT0 & 1 & 9.50 & 1 & 1 & 0.008 & - & - & - & - & - \\
\hline pT2a & 51 & $\begin{array}{l}8.16(9.74) \\
5.00(2.00-66.30)\end{array}$ & 41 & 39 & $\begin{array}{l}0.116(0.207) \\
0.019(0.001-0.897)\end{array}$ & 2 & 10 & 7 & $\begin{array}{l}0.012(0.007) \\
0.010(0.001-0.025)\end{array}$ & 3 \\
\hline pT2b & 62 & $\begin{array}{l}7.05(4.08) \\
5.97(2.59-21.80)\end{array}$ & 50 & 48 & $\begin{array}{l}0.059(0.089) \\
0.018(0.001-0.341)\end{array}$ & 2 & 12 & 11 & $\begin{array}{l}0.032(0.051) \\
0.009(0.001-0.181)\end{array}$ & 1 \\
\hline pT3 & 1 & 19.52 & - & - & - & - & 1 & - & - & 1 \\
\hline
\end{tabular}

Table 2. Results of RTUR-PCa grouped by Gleason's score

\begin{tabular}{|c|c|c|c|c|c|c|c|c|c|c|}
\hline \multirow{4}{*}{$\begin{array}{l}\text { Gleason } \\
\text { Score }\end{array}$} & \multirow{4}{*}{$\begin{array}{l}\text { No. } \\
\text { Patient }\end{array}$} & otal Patients & \multicolumn{4}{|c|}{ Patients treated with 1 operation } & \multicolumn{4}{|c|}{ Patients treated with 2 operations } \\
\hline & & \multirow{3}{*}{$\begin{array}{l}\text { Preop PSA } \\
\text { Mean(SD) } \\
\text { Median(Range) }\end{array}$} & \multirow{3}{*}{$\begin{array}{l}\text { No. } \\
\text { Patient }\end{array}$} & \multicolumn{2}{|c|}{ Patients with stable PSA after } & \multirow{3}{*}{$\begin{array}{l}\text { No. } \\
\text { PSA } \\
\text { Failure }\end{array}$} & \multirow{3}{*}{$\begin{array}{l}\text { No. } \\
\text { Patient }\end{array}$} & \multirow{2}{*}{\multicolumn{2}{|c|}{$\begin{array}{c}\text { Patients with stable PSA after } \\
\text { TUR }\end{array}$}} & \multirow{3}{*}{$\begin{array}{l}\text { No. } \\
\text { PSA } \\
\text { Failure }\end{array}$} \\
\hline & & & & & TUR & & & & & \\
\hline & & & & $\begin{array}{l}\text { No. } \\
\text { Patient }\end{array}$ & $\begin{array}{l}\text { Latest PSA } \\
\text { Mean(SD) } \\
\text { Median(Range) }\end{array}$ & & & $\begin{array}{l}\text { No. } \\
\text { Patient }\end{array}$ & $\begin{array}{l}\text { Latest PSA } \\
\text { Mean(SD) } \\
\text { Median(Range) }\end{array}$ & \\
\hline 4 & 3 & $\begin{array}{l}4.59(0.85) \\
4.41(3.65-5.70)\end{array}$ & 3 & 3 & $\begin{array}{l}0.064(0.074) \\
0.016(0.008-0.168)\end{array}$ & 0 & 0 & - & - & 0 \\
\hline 5 & 3 & $\begin{array}{l}4.39(0.34) \\
4.40(3.96-4.80)\end{array}$ & 2 & 2 & $\begin{array}{l}0.087(0.078) \\
0.087(0.009-0.165)\end{array}$ & 0 & 1 & 1 & 0.001 & 0 \\
\hline 6 & 32 & $\begin{array}{l}6.11(3.62) \\
5.12(2.00-21.40)\end{array}$ & 27 & 27 & $\begin{array}{l}0.088(0.171) \\
0.019(0.001-0.685)\end{array}$ & 0 & 5 & 5 & $\begin{array}{l}0.008(0.007) \\
0.008(0.001-0.020)\end{array}$ & 0 \\
\hline 7 & 56 & $\begin{array}{l}7.25(4.04) \\
5.78(3.11-21.80)\end{array}$ & 43 & 42 & $\begin{array}{l}0.089(0.167) \\
0.017(0.001-0.897)\end{array}$ & 1 & 13 & 10 & $\begin{array}{l}0.035(0.052) \\
0.012(0.001-0.181)\end{array}$ & 3 \\
\hline 8 & 14 & $\begin{array}{l}12.65(16.73) \\
7.10(2.59-66.30)\end{array}$ & 13 & 11 & $\begin{array}{l}0.064(0.102) \\
0.016(0.001-0.344)\end{array}$ & 2 & 1 & 1 & 0.025 & 0 \\
\hline 9 & 7 & $\begin{array}{l}10.95(5.69) \\
8.13(5.00-19.52)\end{array}$ & 4 & 3 & $\begin{array}{l}0.072(0.069) \\
0.036(0.011-0.169)\end{array}$ & 1 & 3 & 1 & 0.013 & 2 \\
\hline
\end{tabular}

Low and stable PSA levels were observed in 88 patients after the first RTUR-PCa. The second operation was performed in 23 patients after a mean period of 21.2 months (range, 5-65 months). No cancer was detected by pathological examination in 5 patients. The second surgery was necessary in $19(46.0 \%)$ of 41 patients before May 2006 but 4 (5.0\%) of 74 patients after that time, suggesting the learning curve effect.

\subsection{Overall Results}

PSA finally stabilized in 106 patients $(92.2 \%)$ as follows: PSA $\leq 0.01 \mathrm{ng} / \mathrm{mL}, 42$ patients; $\leq 0.02,19$ patients; $\leq$ 0.03, 10 patients; $\leq 0.04,6$ patients; $\leq 0.1,10$ patients; $\leq 0.4,7$ patients; $\leq 0.9,12$ patients. PSA failure was diagnosed in 9 patients (7.8\%): 5 patients with pT2a disease, 3 patients with pT2b and 1 patient with pT3. PSA nonrecurrent rates were $90.0 \%$ in pT2a and $95.0 \%$ in pT2b at a mean postoperative follow-up period of 61.9 
months (Figure 1). No significant difference was observed between pT2a and pT2b (chi-square test; $p=0.306$ ). Nonrecurrence rates according to D'Amico's risk group (D'Amico et al., 1998) were $100.0 \%$ in the low-risk group (stage T1c, T2a and PSA level $\leq 10 \mathrm{ng} / \mathrm{mL}$ and Gleason score $\leq 6 ; 35$ patients), $93.0 \%$ in the intermediate-risk group (stage T2b or Gleason score of 7 or $10<$ PSA level $\leq 20 \mathrm{ng} / \mathrm{mL} ; 56$ patients) and $79.0 \%$ in the high-risk group (stage T2c or PSA level $>20 \mathrm{ng} / \mathrm{mL}$ or Gleason score $\geq 8 ; 24$ patients) (Fig. 2). Significan difference is observed in PSA nonrecurrence rate between low-risk and high risk group (chi-square test; $p=0.106$, low- vs. intermediate-risk group; $\mathrm{p}=0.076$, intermediate- vs, high-risk group; $\mathrm{p}=0.0048$, low- vs, high-risk group)

Four patients died 11 to 34 months (mean, 26.3 months) after the surgery with considerable low PSA values between 0.010 and $0.067 \mathrm{ng} / \mathrm{mL}$. The causes of death were gastric cancer, biliary duct cancer, cerebrovascular accident and pneumonia. No patient died of prostate cancer.

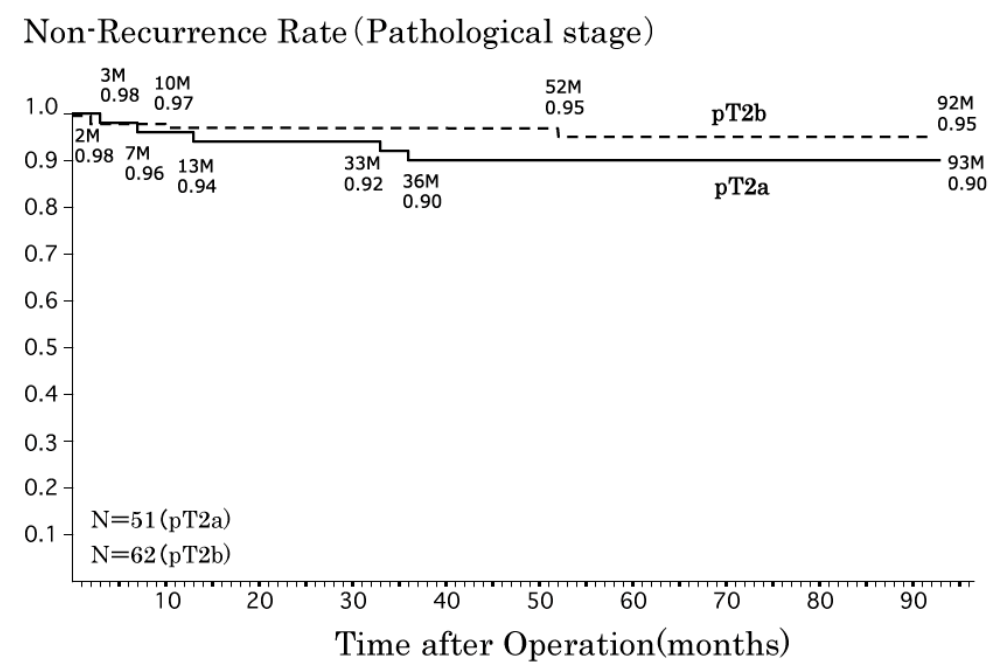

Figure 1. Prostate specific antigen nonrecurrence rate of each pathological stage

(Nonrecurrence rate is analyzed with Kaplan-Merier metnods.)

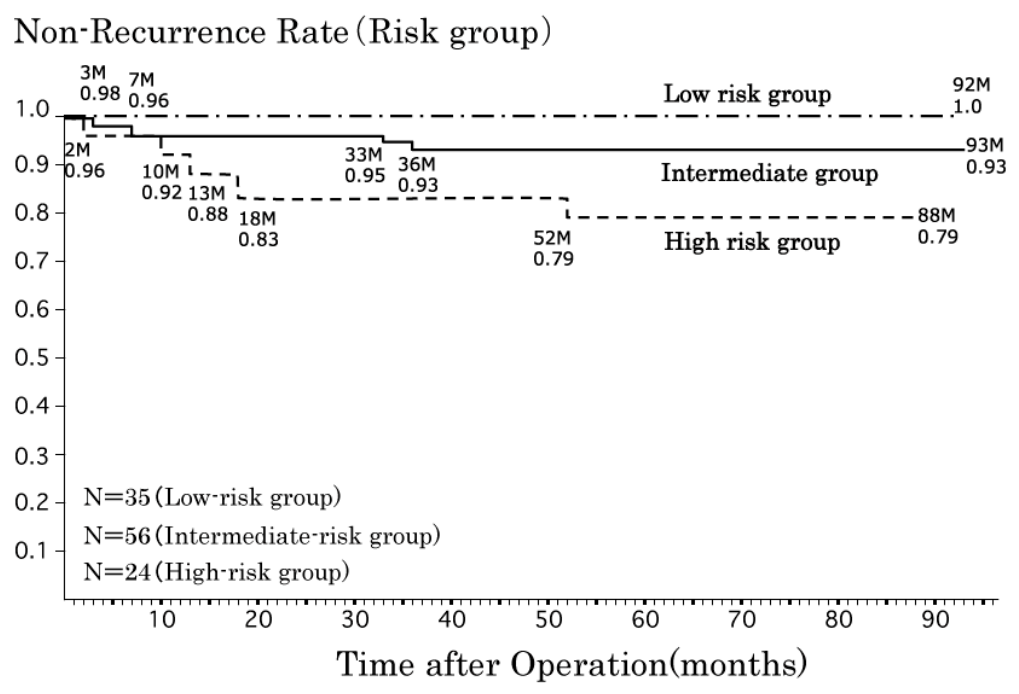

Figure 2. Prostate specific antigen nonrecurrence rate of each risk group

Nonrecurrence rate is analyzed with Kaplan-Merier metnods.

\subsection{Complications}

Extravasation of irrigation fluid is sure to occur during the surgery, but no patients experienced water 
intoxication or electrolyte abnormality, and no patients needed blood transfusion. Approximately half of the patients experienced stress urinary incontinence immediately after the removal of a balloon catheter on the third postoperative day. Incontinence gradually improved and disappeared at 3 months postoperatively. Bladder neck contracture developed in 38 patients $(33.0 \%)$ mostly 3 to 4 months after the surgery. Other complications included cerebral infarction in 1 patient, pulmonary embolism in 1 patient and acute epididymitis in 3 patients, pubic osteitis in 2 patients and clot retention in 2 patients, but none led to patient death. Erectile function was preserved in $20(51.3 \%)$ out of 39 patients who were potent before surgery. Figure 3 is a voiding cystourethrogram 3 weeks after surgery, showing the filling of the seminal vesicle with contrast medium and marked dilation of prostatic urethra with no extravasation.

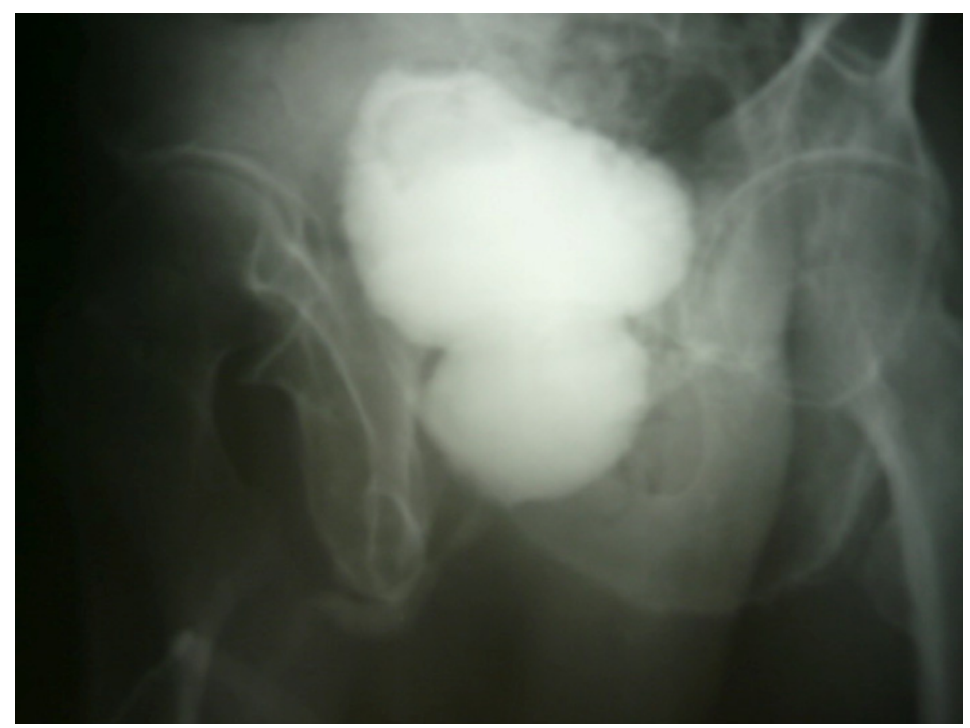

Figure 3. Urethrocystogram three weeks after surgery

Radiopaque contrast is injected into the urethra retrogradely with a patient in the left anterior oblique position. The seminal vesicle is clearly visualized with no extravasation from the prostate bed. Marked expansion of the prostate bed indicates that most prostate tissues were removed by the procedure.

\section{Discussion}

Conclusions have not been reached yet whether PSA screening helps decrease the mortality of prostate cancer or not. Two reports from Europe showed that PSA screening decreased the cancer death by almost half and by up to $31 \%$ respectively. On the other hand, Prostate, Lung, Colon, and Ovarian Cancer Screening Trial (PLCO trial) in the United States, cancer death of the PSA screening group and the control group was about the same though several problems are pointed out concerning the control group. Considering this report, The United States Preventive Services Task Force (USPSTF) announced that PSA screening could not be recommended (LeFevre, 2012). The efficacy of PSA screening is in dispute (Carter et al., 2013; Barry, 2009; Brett \& Ablin, 2011), and the conclusion might be different depending on which points we evaluate more, namely advantage or disadvantage of PSA screening. An advantage of PSA screening is that radical treatment can be applied to the patients by early diagnosis. A disadvantage is that there might be patients who do not need early treatment because of low-grade, small-volume cancer (Ploussard et al., 2011). Then it might be really a problem once severe functional disorders of urinary continence, erectile function and intestinal function developed especially after younger patients had received an aggressive treatment. And it is the most important problem that we cannot prevent such malfunction by the current radical treatment methods. When a patient was diagnosed to have early stage prostate cancer and received an early treatment, it is completely a different disputable point whether the successful radical treatment is to be evaluated or some functional morbidities are to be criticized as drawbacks of early diagnosis, thus the argument does not hang together. We think that PSA screening itself is not very harmful because PSA test is a valuable tumor marker that can lead early detection of prostate cancer. Some studies have confirmed the trends of stage migration of prostate cancer that is diagnosed at younger age and at lower stage (Catalona, Smith, Ratliff, \& Basler, 1993; Aus, Bergdahl, Lodding, Lilja, \& Hugosson, 2007). From the standpoint to evaluate and 
recommend early diagnosis by PSA screening, a less invasive treatment method with lower rate of complications is mandatory. PSA nonrecurrence rate in the present study at the mean postoperative follow-up period of 61.9 months was comparable with that of the current standard therapies. Because RTUR-PCa is considered to be a less invasive surgery and can be performed under spinal anesthesia, it can be applied as a radical therapy to the elderly patients who have high-risk cancer that can be progressive. As RTUR-PCa is a repeatable procedure, then theoretically, cancer foci are possible to be eradicated. The procedure also can be appropriately applied to low-volume, low-grade prostate cancer that have increased as a result of stage migration caused after the introduction of PSA-based mass screening. We previously reported the oncological and functional outcomes of RTUR-PCa in the patients with incidental cancers (T1) that were diagnosed by TURP (Morita \& Matsuura, 2013). The results were satisfactory in both points of PSA nonrecurrence rate comparable with present standard procedures and preserved urinary continence. Urinary incontinence was not observed in the present study. Erectile function was not reserved in some of the patients, but it might be resolved by nerve-sparing TUR-PCa that we reported as an option of focal therapy (Morita \& Matsuura, 2012). The most frequent postoperative complication was bladder neck contracture that occurred in $33.0 \%$ of patients 3 to 4 months after surgery (Grade IIIa by Clavien classification). This had been anticipated because of aggressive bladder neck resection to achieve radicality. It was easily treated by optical urethrotomy under caudal block. The present study might not be a well-designed one, including many patients who were taking preoperative hormonal therapy. In patients with prostate hyperplasia and taking $50 \mathrm{mg}$ /day of chlormadinone acetate for 16 weeks, PSA levels are reported to return to the baseline levels 32 weeks after discontinuation (Fujimoto et al., 2011). In the present study the effect of preoperative hormonal therapy on the most recent PSA levels can be therefore minimal or negligible. Dissemination of cancer cells during TUR-PCa is another disputable point and remains to be solved (Levine, Cisek, Mulvihill, \& Cohen, 1986; Zelefsky, Whitmore, Leibel, Wallner, \& Fuks, 1993; Pansadoro et al., 1991; Trygg, Ekengren, Farahmand, Persson, \& Hahn, 1998). Considering our clinical results of RTUR-PCa with a mean follow-up period of 5.2 years, dissemination of cancer cells may be minimum or almost ignored.

\section{Conclusions}

Early diagnosis is an important primary condition to manage any cancers in any organs. Many urologists might feel a little uncomfortable when prostate cancer was suggested to be an exception for this. Radical or focal TUR-PCa that we reported might achieve better oncological and functional outcomes in the patients who were diagnosed to have early-diagnosed prostate cancer. Our less invasive procedure might be thought to be an encouraging surgical option though longer follow-up period with more patients will be necessary to obtain a definite conclusion.

It has been the subject of current debate whether PSA screening can really reduce mortality from prostate cancer or not, and PSA screening can result in overdiagnosis and overtreatment or not. Radical TUR-PCa and focal TUR-PCa have almost the same satisfactory oncological outcomes compared with the current standard radical treatment, and can be a hopeful treatment option with reserved urinary continence and erectile function. Spread of TUR-PCa might help the dispute be solved concerning the overdiagnosis and overtreatment of PSA-based mass screening.

\section{Rerefrences}

Andriole, G. L., Crawford, E. D., Grubb, R. L., Buys, S. S., Chia, D., Church, T. R., ... Berg, C. D. (2009). Mortality results from a randomized prostate-cancer screening trial. The New England journal of medicine, 360(13), 1310-9. http://dx.doi.org/10.1056/NEJMoa0810696

Aus, G., Bergdahl, S., Lodding, P., Lilja, H., \& Hugosson, J. (2007). Prostate cancer screening decreases the absolute risk of being diagnosed with advanced prostate cancer--results from a prospective, population-based randomized controlled trial. European urology, 51(3), 659-64. http://dx.doi.org/10.1016/j.eururo.2006.07.012

Barry, M. J. (2009). Screening for prostate cancer--the controversy that refuses to die. The New England journal of medicine, 360(13), 1351-4. http://dx.doi.org/10.1056/NEJMe0901166

Barry, M. J., Gallagher, P. M., Skinner, J. S., \& Fowler, F. J. (2012). Adverse effects of robotic-assisted laparoscopic versus open retropubic radical prostatectomy among a nationwide random sample of medicare-age men. Journal of clinical oncology: official journal of the American Society of Clinical Oncology, 30(5), 513-8. http://dx.doi.org/10.1200/JCO.2011.36.8621

Binder, J., \& Kramer, W. (2001). Robotically-assisted laparoscopic radical prostatectomy. BJU international, 87(4), 408-10. http://dx.doi.org/10.1046/j.1464-410x.2001.00115.x 
Brett, A. S., \& Ablin, R. J. (2011). Prostate-cancer screening--what the U.S. Preventive Services Task Force left out. The New England journal of medicine, 365(21), 1949-51. http://dx.doi.org/10.1056/NEJMp1112191

Carter, H. B., Albertsen, P. C., Barry, M. J., Etzioni, R., Freedland, S. J., Greene, K. L., ... Zietman, A. L. (2013). Early Detection of Prostate Cancer: AUA Guideline. The Journal of urology, 190(2), 419-26. http://dx.doi.org/10.1016/j.juro.2013.04.119

Catalona, W. J., Smith, D. S., Ratliff, T. L., \& Basler, J. W. (1993). Detection of organ-confined prostate cancer is increased through prostate-specific antigen-based screening. JAMA : the journal of the American Medical Association, 270(8), 948-54. http://dx.doi.org/10.1001/jama.1993.03510080052031

Chou, R., Croswell, J. M., Dana, T., Bougatsos, C., Blazina, I., Fu, R., ... Lin, K. (2011). Screening for prostate cancer: a review of the evidence for the U.S. Preventive Services Task Force. Annals of internal medicine, 155(11), 762-71. http://dx.doi.org/10.7326/0003-4819-155-11-201112060-00375

D’Amico, A. V, Whittington, R., Malkowicz, S. B., Schultz, D., Blank, K., Broderick, G. A., ... Wein, A. (1998). Biochemical outcome after radical prostatectomy, external beam radiation therapy, or interstitial radiation therapy for clinically localized prostate cancer. JAMA : the journal of the American Medical Association, 280(11), 969-74. http://dx.doi.org/10.1001/jama.280.11.969

Fujimoto, K., Hirao, Y., Ohashi, Y., Shibata, Y., Fuji, K., Tsuji, H., ... Boku, E. (2011). Changes in serum prostate specific antigen and testosterone levels after chlormadinone acetate treatment in patients with benign prostatic hyperplasia: a prospective multicenter clinical study. Hinyokika kiyo. Acta urologica Japonica, 57(4), 177-83.

Hu, J. C., Gu, X., Lipsitz, S. R., Barry, M. J., D’Amico, A. V, Weinberg, A. C., \& Keating, N. L. (2009). Comparative effectiveness of minimally invasive vs open radical prostatectomy. JAMA: the journal of the American Medical Association, 302(14), 1557-64. http://dx.doi.org/10.1001/jama.2009.1451

Hugosson, J., Carlsson, S., Aus, G., Bergdahl, S., Khatami, A., Lodding, P., ... Lilja, H. (2010). Mortality results from the Göteborg randomised population-based prostate-cancer screening trial. The lancet oncology, 11(8), 725-32. http://dx.doi.org/10.1016/S1470-2045(10)70146-7

LeFevre, M. (2012). Screening for prostate cancer: current recommendation. The USPSTF recommends against PSA-based screening for prostate cancer 2012.

Levine, E. S., Cisek, V. J., Mulvihill, M. N., \& Cohen, E. L. (1986). Role of transurethral resection in $\begin{array}{llll}\text { dissemination of cancer of prostate. Urology, 28(3), 179-83. } & \end{array}$ http://dx.doi.org/10.1016/0090-4295(86)90038-5

Menon, M., Shrivastava, A., Kaul, S., Badani, K. K., Fumo, M., Bhandari, M., \& Peabody, J. O. (2007). Vattikuti Institute prostatectomy: contemporary technique and analysis of results. European urology, 51(3), 648-57; discussion 657-8. http://dx.doi.org/10.1016/j.eururo.2006.10.055

Morita, M., \& Matsuura, T. (2009). Radical Treatment of Localized Prostate Cancer by Radical Transurethral Resection of the Prostate. Current Urology, 3(2), 87-93. http://dx.doi.org/10.1159/000189690

Morita, M., \& Matsuura, T. (2011). Radical transurethral resection of the prostate: A possible radical procedure against localized prostate cancer with almost no postoperative urinary incontinence in Prostate Biopsy. (N. K. Bissada, Ed.) (1st ed., pp. 19-34). Rijeka, Croatia: InTech. http://dx.doi.org/10.5772/1491

Morita, M., \& Matsuura, T. (2012). Management of Localized Prostate Cancer by Focal Transurethral Resection of Prostate Cancer: An Application of Radical TUR-PCa to Focal Therapy. Advances in urology, 2012(3), 564372. http://dx.doi.org/10.1155/2012/564372

Morita, M., \& Matsuura, T. (2013). Successful treatment of incidental prostate cancer by radical transurethral resection of prostate cancer. Clinical genitourinary cancer, 11(2), 94-9. http://dx.doi.org/10.1016/j.clgc.2012.09.012

Pansadoro, V., Sternberg, C. N., DePaula, F., Florio, A., Giannarelli, D., \& Arcangeli, G. (1991). Transurethral resection of the prostate and metastatic prostate cancer. Cancer, 68(9), 1895-8. http://dx.doi.org/10.1002/1097-0142(19911101)68:9<1895::AID-CNCR2820680908>3.0.CO;2-B

Ploussard, G., Epstein, J. I., Montironi, R., Carroll, P. R., Wirth, M., Grimm, M.-O., ... van der Kwast, T. H. (2011). The contemporary concept of significant versus insignificant prostate cancer. European urology, 60(2), 291-303. http://dx.doi.org/10.1016/j.eururo.2011.05.006 
Reuter, M. A., \& Dietz, K. (2009). Radical transurethral resection of the prostate. An alternative therapy for the treatment of prostate cancer. Der Urologe. Ausg. A, 48(7), 740-7. http://dx.doi.org/10.1007/s00120-009-1982-8

Reuter, M. A., Reuter, H. J., \& Epple, W. (1991). Total transurethral electroresection of carcinoma of the prostate. Archivos españoles de urología, 44(5), 611-4.

Roobol, M. J., Kerkhof, M., Schröder, F. H., Cuzick, J., Sasieni, P., Hakama, M., ... Auvinen, A. (2009). Prostate cancer mortality reduction by prostate-specific antigen-based screening adjusted for nonattendance and contamination in the European Randomised Study of Screening for Prostate Cancer (ERSPC). European urology, 56(4), 584-91. http://dx.doi.org/10.1016/j.eururo.2009.07.018

Trygg, G., Ekengren, J., Farahmand, B. Y., Persson, P. G., \& Hahn, R. G. (1998). Operative course of transurethral resection of the prostate and progression of prostate cancer. Urologia internationalis, $60(3)$, 169-74. http://dx.doi.org/10.1159/000030244

Valdivia Uría, J. G., \& López López, J. A. (1989). Is the use of transurethral resection adequate in the therapy of carcinoma of the prostate?. Archivos españoles de urología, 42(Suppl 2), 179-86.

Wilt, T. J., Brawer, M. K., Barry, M. J., Jones, K. M., Kwon, Y., Gingrich, J. R., ... Fox, S. (2009). The Prostate cancer Intervention Versus Observation Trial:VA/NCI/AHRQ Cooperative Studies Program \#407 (PIVOT): design and baseline results of a randomized controlled trial comparing radical prostatectomy to watchful waiting for men with clinically locali. Contemporary clinical trials, 30(1), 81-7. http://dx.doi.org/10.1016/j.cct.2008.08.002

Zelefsky, M. J., Whitmore, W. F., Leibel, S. A., Wallner, K. E., \& Fuks, Z. (1993). Impact of transurethral resection on the long-term outcome of patients with prostatic carcinoma. The Journal of urology, 150(6), $1860-4$.

\section{Copyrights}

Copyright for this article is retained by the author(s), with first publication rights granted to the journal.

This is an open-access article distributed under the terms and conditions of the Creative Commons Attribution license (http://creativecommons.org/licenses/by/3.0/). 